\title{
Karikatür ve İfade Özgürlüğü
}

\author{
DOI: $10.26466 /$ opus.515034 \\ *
}

\section{$\underline{\text { Zeynep Burcu Șahin }}^{*}$}

* Dr. Öğretim Üyesi, İstanbul Gelişim Üniversitesi, Uygulamalı Bilimler Y. O., İstanbul/Türkiye E-Posta: zbsahin@gelisim.edu.tr

ORCID:0000-0003-1870-3073

\section{Öz}

Karikatür, değindiği konuları kısa ve öz biçimde ele alan; genellikle güldürmek, düşündürmek ve ayn zamanda iğnelemek için abartan ve bazen de gerçeği çarpıtan bir çizgi resim türüdür. Gazetecilerin elindeki masum görünüşlü bu silah, sadeliği ve kolay anlaşılır haliyle aynı zamanda en etkin olanıdır. Gazeteci, karikatürle mizahı kullanarak hiçbir ispat yükümlülü̈̆̈̈ taşımadan, geniş kitleleri kendi düşüncesinde ikna edebilir; bunun için ayrıntıl açıklamalara girmesi ya da düşüncelerini ispat etmesi gerekli değildir. Karikatür, zaten "abartı"dan oluşmaktadır ve doğruluk iddiası taşımaz. Bununla birlikte, ilk bakıştaki iddiasız görünümüne karşıllk karikatür, tarih boyunca halk üzerindeki etkisinin farkında olan siyasi iktidarların korktukları ve engellemeye çalıştıkları bir araç olmuştur. Siyasi bir hiciv biçimi olarak karikatür, yasal metinlere basının ve basın özgürlüğ̈̈̈nün bir parçası olarak dâhil edilmeden çok önce sinırlamalar ve sansür açısından basının kaderini paylaşmaya başlamıştır. Bu açıdan bakıldığında, karikatürün anavatanı olan İtalya yerine, 17. yy.ın başlarında diğer Avrupa ülkelerine görece demokratik bir rejim kuran Ingiltere'de benimsenip gelişmesi tesadüfi değildir. Karikatür günümüzde de siyasi ve ekonomik iktidarlar için bir tehdit oluşturmakta; iktidarlar ve karikatüristler arasında bu doğrultuda hukuki anlaşmazliklar doğmaktadır. Bu noktada, karikatürün de basın özgürlüğ̈̈ kapsamında ele alındiğı ve basın özgürlüğ̈̈̈ ile aynı hak, sorumluluk ve sinırlamalara tabi tutulduğ u unutulmamalıdır. Ülkemizde mizah dergilerine ve karikatüristlere yönelik davalar sadece hakaret davalarından oluşmamakta; dini değerleri aşağılama, müstehcenlik ve 301. madde gibi TCK kapsamında suç olarak düzenlenen diğer unsurlar da mizah dergilerinin yasal yaptırımlar ya da tehdit ve baskıyla karşılaşmasına neden olabilmektedir. Bu çalışmanın konusunu karikatürün ifade özgürlüğ̈̈ çerçevesinde değerlendirilmesi oluşturmaktadır. Çalışmanın amact, karikatürün ifade özgürlüğ̈̈ bağlamında meşru sınırlarının belirlenmesine yardımcı olmaktır. Çalışmada esas olarak literatür taraması kullanılmış olup rastgele örneklem yöntemiyle çeşitli davalar incelenmiştir.

Anahtar Kelimeler: Mizah, Karikatür, İfade Özgürlüğü, Sansür, Yayın Yasakları 


\title{
Caricature and The Freedom of Speech
}

\begin{abstract}
Caricature deals with the subjects it deals with in a short and concise way; it is a kind of cartoon picture that usually exaggerates and sometimes distorts the truth to laugh, think and at the same time pinch. This innocent gun in the hands of journalists is the most effective at the same time as it is simplicity and easy to understand. The journalist can persuade large masses in their own minds before carrying out any proof of obligation using comic strips. It is not necessary to elaborate on this or to prove their opinions. Cartoons are already composed of "exaggeration" and do not bear the righteousness. for all that the caricature has become a means by which political powers who are aware of the influence over the people throughout history have been frightened and trying to prevent. As a form of political satire, the caricature began to share the fate of the press in terms of restrictions and censorship long before it was included in legal texts as part of the press and freedom of the press. From this point of view, it is no coincidence that the caricature adopted and developed in England, which established a democratic regime relative to other European countries at the beginning of the 17th century, rather than the homeland of Italy. Caricature poses a threat to political and economic power, legal disputes arise between the ruling and cartoonists in this direction. At this point, it should not be forgotten that the cartoons are also subjected to the same rights, responsibilities and limitations as the freedom of the press, which is covered by press freedom. The lawsuits against humor magazines and caricaturists in our country do not consist solely of insults humiliating religious values, obscenity and Other elements, such as Article 301, which are organized as criminal offenses under the Turkish Penal Code, may also cause humorous journals to face legal sanctions or threats and oppression. The subject of this study is the evaluation of caricature within the framework of freedom of expression. The aim of the study is to help to determine the legitimate limits of caricature in terms of freedom of expression. The literature review was mainly used in the study and various cases were investigated by random sampling method.
\end{abstract}

Keywords: Humor, Caricature, Freedom of Expression, Censorship, Broadcasting Prohibitions 


\section{Giriş}

Mizahın ve gülmenin bir tehdit olarak kabul edilmesi yeni bir kavram değildir. Tarih boyunca farklı teorilerle açıklanmaya çalışılan gülme, çoğunlukla bir meydan okuma olarak algılanmıştır. Nitekim özüne indiğimizde, karşı tarafa fiziksel ve psikolojik bir meydan okuma içeren gülmenin, çok da masum bir eylem olmadığı görülecektir. "Tek söz söylemeden, bir kahkaha en büyük zorbaların tehditlerinde gedik açabilir ya da en can sıkıcı kimseleri yola getirebilir. Birçoğumuz, çok erken yaşlarda, yerinde bir kahkahayla ne büyük bir güç ortaya çıkarabileceğimizi öğreniriz (Sanders, 2001, s.33)."

Deniz Gezmiş'in duruşma esnasında gülmesi ve hâkimin "Neden gülüyorsun?" sorusuna verdiği "Duvarda adalet yazıyor, ona gülüyorum" cevabı, belki de yukarıda açıkladığımız meydan okumaya verilebilecek en iyi örneklerden birisidir. Bu gülüş, sonu idamla bitecek bir yargılama sürecinin ağırlığını bir an için ortadan kaldırmış; kısa bir süre için de olsa sanık sandalyesinde oturanlara üstünlük ve dokunulmazlık sağlamıştır. Nitekim gülmenin tek başına varlığı bile, içgüdüsel olarak bir uyumsuzluğun varlığına işaret eder. Eğer kahkaha varsa bir nedeni olmalıdır. Ve meydan okuyan bir kahkaha için geliştirilmiş bir savunma henüz yoktur; yine mizahın kendisi dışında...

Gezmiş'in kahkahası iki noktada önem kazanmaktadır; kahkahayla ortamın ağırlığını dağıtmış; espri ile ise mantığı kesintiye uğratmıştır. Kanımızca en ilginç tarafı ise bunu büyük ihtimalle, tarihe geçeceğini bilmeksizin ve herhangi bir amaç gütmeksizin içgüdüsel olarak yapmış olmasıdır. "Espri yapmak gerçekliği kendi adımıza keşfetme olanağı verir bize: Espriler beklentileri alt üst eder. Kendi gerçekliklerini yaratırlar. Mantığı kesintiye uğratırlar (Sanders, 2001, s.51)."

Temelini hangi kurama dayandırırsak dayandıralım mizahın -özellikle kendileri hedef alındığında- iktidarlar için tehlike arz ettiği açıtır. Bununla birlikte gülme, fiziksel anlamda bir rahatllk verir. Nitekim korkulan nesne ya da kişinin korkulacak özellikleri törpülenmiş ve gülünçleştirilmiştir. Özellikle kaostan beslenen ve otoriteye dayanan iktidar ve baskı grupları için ise bu rahatlama başlı başına bir tehdittir.

Benzer bir örnek de Charlie Chaplin'in "Büyük Diktatör" oyununda karşımıza çıkmaktadır. Sanders, Kahkahanın Zaferi adlı eserinde Charlie 
Chaplin'in Nazi tehdidinin had safhada sürdügü 1940'larda Avrupa'nın bu tehdidini nasıl tepetaklak ettiğini anlatır;

"Soytarı, burlesk, mimci, akrobatik dansçı Chaplin, Avrupa'nın Tehdidi'ni tepetaklak etmişti. Nasıl da tedirgin edici: Seyirciler gülsünler mi, gülmesinler mi bilmiyorlard.

... Gülmenin gerçekten gücü varsa, en güçlü kötülü̈̆ü bile yadsıma gücü olmahıdır. Dolayısıyla, Adolf Hitler maskesine bürünüp nihai diktatörün bir sürü aşırı jestle -bir kahkahayla- kolayca yok edilebileceğini göstererek bu gücü sinıyordu (Sanders, 2001, s.302)."

Günümüzde mizahın muhalefet gücünün en keskin ve net göründügü alan olarak karşımıza karikatürler çıkmaktadır. Ana akım medya organlarına oranla görece bağımsız yapıları ile karikatür dergileri ve karikatüristler mizahın gücünü kullanarak her türlü ekonomik, siyasi ya da toplumsal olayı eleştirebilmekte; bunun yanında çoğu zaman durumun vahametini tebessümle azaltmaktadırlar.

Doğal olarak karikatür, doğuşundan itibaren, mizahla nasıl mücadele edeceğini bilemeyen mevcut iktidar erklerinin hedefi haline gelmiştir. Karikatür, bir anlamda güçlü olan ve korkulanın güçsüzleştirilmesi; çeşitli özellikleri abartılarak gülünç hale getirilmesidir. Bu yönüyle de iktidarlar üzerinde kullanılması kaçınılmaz görünmektedir.

\section{Mizah}

Türkçe karşıllı̆ı "gülmece" olan mizah sözcüğü dilimize Arapçadan geçmiş olup aslı "müzah"tır. Türk Dil Kurumu'nun sözlüğünde gülmece, "eğlendirme, güldürme ve bir kimsenin davranışlarına incitmeden takılma amacını güden ince alay, mizah, humor" olarak tanımlanmıştır (http://www.tdk.gov.tr/index.php?option=com_gts\&arama=gts\&guid=TDK.GTS.5730897dcc16c0.90659314, Erişim Tarihi: 09.05.2016). Mizahın kökeninde eğlence ve hoşgörü yer alır (Öngören, 1983, s.11). Bu saptama da mizahın içinde hoşgörüyü gerektirecek bir durumun varlığına işaret etmektedir. "Mizah, topluluk durumundaki insanların yaşantıya koydukları sosyal, politik, ekonomik ve cinsiyet baskılarına dokunmakla 
onları ırgalamakla hoşgörüyü harekete geçirir (Öngören, 1983, s.11).” Bu eylemde çoğu zaman, kötü ve görece güçlü olanı güçsüz ve gülünç bir hale getirerek sıradanlaştırma; toplumun diğer öğeleriyle eş konuma indirgeme gözlemlenmektedir. Bir bakıma otoriteye yapılan saldırı söz konusudur. Diğer yandan mizah, özellikle toplumun sıkıntılı dönemlerinde geçici de olsa bir rahatlama, sorunlardan uzaklaşma sağlar. Ancak bu özelliğiyle iktidarların işine oldukça yarayabilecek mizah, bizzat iktidarların mizahın konusu haline getirilmesi ve eleştiri yönünün ağırlık kazanmasıyla iktidarların hedefi haline gelmiş; ortaçağdan bu yana baskı altında tutulmaya çalışılmıştır. Nitekim mizah belirli ve var olan kişileri hedef aldıktan sonra, buna uygun bir hoşgörü anlayışının geliştirilmesi gerekli olmuştur (Öngören, 1983, s.15). Bu hoşgörü de günümüzde kaynağını demokrasi geleneğinden ve yasalardan almaktadır.

“Toplumsal gerçekliğe gülünç, sıra dışı, eğlenceli, satirik bir dille yaklaşımın adı olan mizahın karakteri eleştirel olmasıdır. Batı kültüründe 'humour' olarak geçen mizah, toplumsal işlevi ile değerlendirilmekte, güldürürken sorgulamayı hatta yıkıcılığı içermektedir (Avc1, 2003)." İçerik olarak farklılaşsa da her dönemde mizaha yüklenen bu toplumsal işlev, bir bakıma kökeninde yer alan eğlence ve hoşgörüyü de açıklamaktadır. Nitekim günümüzde mizaha yüklenen iki farklı işlev vardır; muhafazakâr olan yaklaşım toplumsal sorunların mizahla aşlabileceğine inanır, tam tersi yaklaşım ise mizahın eleştirel bir gücü olduğunu ve iktidarı sorgulaması gerektiğini öne sürer (Avc1, 2003). Her iki yaklaşım da içerik olarak farklılık arz etse de mizahın toplumda ters giden durumlarda bir işlevi olduğunu savunmaktadır.

İnsanların topluluk halinde yaşamaya başladığı andan itibaren var olan mizah, toplumsal yaşamın gerek ve ihtiyaçlarına göre zaman içinde türlere ayrılmaktadır. Bu türler sabit kabul edilmez. Tarihsel süreç içinde gelişen ve değişen toplumsal yaşam biçimleri farklı mizah türlerini de beraberinde getirmektedir. Nitekim sözlü dönemde hiçbir etkinliğe sahip olmayan karikatürün bir mizah türü olarak basınla birlikte doğması da bu durumun bir ürünü olarak karşımıza çıkmaktadır. Karikatür, basının dördüncü güç olarak iktidarı denetleme, halkı aydınlatma ve muhalefet gibi görevlerini -mizahın kökeninde yer alan eğlence ve hoşgörü kavramlarından aldığı destekle- oldukça etkili ve sert bir dille gerçekleştirme hakkını kendinde görmüştür. 
Kavramsal tanım olarak güldürü öğesi üzerinde durulsa da mizah genel kabul görmüş bir toplumsal eleştiri yöntemi olarak da görülmektedir. Mizah, "ciddi olanın, gücüne erişilmez olan iktidar sahiplerinin, onlara dayanak olan dar görüşlülüğün, bağnazca davranışların gülünçleştirilmesi, reel hayatın karşısında tek tek kaldıkları sürece boyun eğen sıradan insanların, topluca yüreklenme, nefes alma, bir çözüm arama çabası olmuştur (Oskay, 2000, s.25)." İnce bir zekâ ve güçlü bir gözlem yeteneği gerektiren mizah, bu nitelikleriyle sahibini korur ve güldürü unsurunun da desteğiyle baskı altında tutulması, kontrol edilmesi güç bir hal alır.

“Komik, trajik gibi bir estetik kategoridir. İkisi de yaşanan gerçeklikle düşlenen (ideal) arasındaki çelişkiler ve çatışmalardan doğar (Çeviker, 1986, s.55)." Bu noktadan bakıldığında mizahın temelinde eleştirinin yer alması kaçınılmaz bir durum olarak karşımıza çıkmaktadır. Nitekim mizah da olması gerekenle olan arasındaki farkı göstermekte; bunun için çoğunlukla abartıdan faydalanmaktadır.

"Mizahın kökenlerine indiğimiz zaman, şunu görürüz ki; mizah daima hâkim sınıflara karşı gösterilen bir tepkinin ifadesidir. Bu tepki toplumun alt tabakalarından, iktidarda kim varsa ona doğru yönelen son derece sivil bir eylemdir (Arık, 1998, s.43)." Mizah ustaları için iktidarda kimin olduğu da anlamsızdır; mizah eleştirmek, başkaldırmak için vardır ve söz konusu iktidarlarsa eleştirilecek bir şeyler her zaman mevcuttur.

Her ne kadar evrensel bir boyutu da olsa, mizah, içinde üretildiği toplumun kültürü ile şekillenmektedir. Toplumun üyeleri tarafından kültürel kodları çerçevesinde anlamlandırılır. Bu bağlamda Türk mizahı, tarihten gelen özellikleriyle Batı'dan farklılık arz eder. Bununla birlikte toplumlar arasında farklılaşan mizah anlayışı mizah ve hakaret arasındaki sınırın belirlenmesi üzerine çeşitli tartışmaları da beraberinde getirmektedir.

Mizahı ve gülmeyi açıklamaya çalışan çeşitli kuramlar mevcuttur. Bununla birlikte gülmenin tek bir kuramla açıklanması mümkün gözükmemektedir. Gülmeyi açıklayan kuramlardan her biri, bir anlamda gülmenin çeşitlerini anlatmaktadır. Söz konusu kuramlar şunlardır;

- Üstünlük Kuramı: Kökeni Platon ve Aristo'ya kadar götürülebilen en eski ve en yaygın gülme kuramı gülmenin bir insanın diğer insanlar üzerindeki üstünlük duygularının dişa vurumu olduğudur (Morreal, 1997, s.8). Thomas Hobbes tarafından geliştirilmiştir. Bu 
kurama göre karşımızdakine bizde olmadığını varsaydığımız kusurları için güleriz. Ludovici'ye göre gülme herhangi bir duruma, düşmana ondan daha güçlü ve daha iyi uyum sağladığımızı anlatma yolumuzdur (Morreal, 1997, s.8). Bir nevi meydan okuma içerir ve karşı tarafa olan üstünlüğümüzü belirttiğimiz bir eylemdir.

- Rahatlama Kuramı: Rahatlama kuramına göre mizah, bastırılmış duyguların dışa vurumudur. Özellikle baskıcı rejimlerde halkın bastırılmış duygularını dışa vurmasını sağlayarak bir nevi dengeleyici toplumsal işlev gösterir. Halk mizahın inceliği ve koruması altına alınmış eleştirilere ve abartıdan faydalanılarak hazırlanmış gülünçlüklere gülerek rahatlar ve kendini eşitlenmiş hisseder.

- Uyumsuzluk Kuramı: Uyumsuzluk kuramına göre gülme, umulmadık, mantıksız ya da uygunsuz bir şeye karşı gösterilen zihinsel tepkidir (Morreal, 1997, s.24). Buna göre beklenmedik son içeren her şey bizi güldürebilir.

Mizah kuramları açısından baktığımızda karikatürün daha ziyade Rahatlama Kuramına denk geldiği görülmektedir.

\section{Politik Mizah ve Karikatür}

İtalyanca kökenli bir kelime olan karikatür, Cari-care (saldırı)dan türemiştir. Doğduğu günden bu yana aynı zamanda belirgin bir sanatsal yetenek gerektirmekle beraber, "öncelikle toplumsal aksaklıkları konu edinen ve tümüyle topluma dayalı, topluma dönük, toplumla birlikte var olan bir sanat niteliğì" taşımaktadır (Balcıoğlu, 1987, s.7-8). Karikatür, ele aldığ1 konuları kısa ve öz biçimde ele alan; genellikle güldürmek, düşündürmek ve aynı zamanda iğnelemek için abartan ve bazen de gerçeği çarpıtan bir çizgi resim türüdür. Bir başka deyiş̧le karikatür, mizahın çizgi yoluyla verilmesinden ibarettir (Arık, 1998, s.48). Şemsettin Sami, karikatürü şöyle tanımlamaktadır;

"Eğlence ve güldürmek için yapılan tuhaf resim, karikatür. Fena ve kaba resim. mec. Kiyafet ve tavrı gülünç adam (Kamus-1 Turki'den akt. Çeviker, 1986, s.55)." Tarihsel bağlamda incelendiğinde de karikatürün ilk olarak abartma ve gülünç gösterme işlevinin ön plana çıtı̆̆g görülmektedir. 
Günümüz ünlü mizahçlarının ve karikatüristlerinin karikatür üzerine tanımlamalarına baktığımızda ise ilk göze çarpan nokta karikatürün "sanatsal bir ifade biçimi" olarak değer kazanmış olmasıdır. Turhan Selçuk, karikatürü "çizgiyle mizah yapma sanatı" olarak tanımlamıştır (http://www.akdagsaydut.com.tr/as_yazilar_orta.php?subac-

tion=showfull\&id=1186940446\&archive=\&start_from=\&ucat=10\&. Erişim Tarihi: 02.03.2018). Karikatürün daha çok sanatsal yönüne vurgu yapan Selçuk'a karşın Abidin Dino ise "Karikatürün içtimai silah olarak yazıdan, şiirden ve resimden daha kuvvetli olduğu bir gerçektir. Büyük halk kitlelerine hitap etmek isteyenler için karikatürün en kısa yol olduğu bilinmektedir (Özocak, 2011, s.264)." diyerek karikatürü düşünceyi ifade etmede etkin bir araç olarak gördügünü göstermektedir.

"Karikatür, sanatın "anlama, anlamlandırma ve anlatma" çabalarının en yalın ve en sert biçimde görüldüğü alanıdır. Bir fikri eğmeden bükmeden anlatan karikatür, bireylerin düşünce dünyalarında sarsıntılara sebep olur. Bu tahribattan sonra birey kendini ve toplumunu sorgular (http://www.umut.org.tr/Upload/Document/document_ca5f01b9796a40f782b43262be5fd0a9.pdf, Erişim Tarihi: 19.02.2015)." İlhan Selçuk'a göre karikatür, mizahın soyutlanıp çizginin geometrisine varmış halidir (Kar, 1999, s.20). Orhan Koloğlu ise "bir kişi, tip ya da eylemin çizgiyle çarpitılmış, abartılmış sunuluşu" (Koloğlu, 2005, s.21) olarak tanımlar karikatürü.

Bununla birlikte karikatürü ve mizahı salt bir muhalefet aracı olarak görmek de kanımızca eksik ve yanlış bir bakış açısı doğuracaktır. Nitekim karikatür de mizah da aynı zamanda sanatsal boyutuyla karşımıza çıkmakta ve özünde gülümsetme güldürme hedefi taşımaktadır. Bir başka deyişle karikatür kusurları abartıp büyülterek gülümsetmeyi hedefler. Eleştiri vasfını iktidarların ciddi yüzüne karşı çok da adil olmayan bir silahla- okuyucuyu gülümseterek- yerine getirir. Bu da ciddi bir hava taşıyan siyasete ve politikacılara yönelik en büyük tehdit olarak karşımıza çıkmaktadır.

"Karikatür ya olağan bir görüntü içinde olmadık sınıfları bir araya getirmek ya da günlük hayatta olmayan bir görüntü tablosu içinde olağan bir durumu sergileyerek, mizahı sağlama tekniğinden kurtulabilmiş demek değildir. Zaten bu kök ilişkiden uzaklaşması da beklenemez (Öngören, 1983, s.47)." Bir diğer deyişle karikatür, mizah öğesini olağan ile 
olağandışının bir arada sunulması ile sağlamakta; bunun için de abartıdan faydalanmaktadır. Bu noktada, karikatürün özünün abartıdan ve çelişkilerden oluştuğunu söylemek mümkündür.

Nietzche'ye göre, kabalık, çarpıtma ve karikatür yoluyla karakteri abartma, enerjik bir ruhsal yaşamın ve estetik bir yaşamın özünü oluşturmaktadır (Nietcche'den aktaran Sanders, 2001, s.281). Nitekim her ne kadar diğer mizah çeşitlerine göre yeni olmasından dolayı köklü geleneklere sahip olmasa da karikatürde genel itibariyle iki mizah öğesi gözlemlenmektedir; insanın yüz ya da gövde orantılarını olağandışı büyütmek ve küçültmekle alışılmadık görüntüler elde etme ve/veya insan başı ile bir kuş ya da at gövdesini birleştirerek olmadık iki sınıfı bir araya getiren önermeler gibi, mizahı sağlamak eğilimi (Öngören, 1983, s.46).

Karikatürün günümüzdeki anlamıla ortaya çıkması, basının günümüzdeki etkinliğini kazanması ile mümkün olmuştur. Bir başka deyişle mizah, kâğıda geçirilirken dönemin şartlarına, beklentilerine ve ihtiyaçlarına yönelik yeni bir araç edinmiş̧ir. Sanders, bu durumu dönemin şartlarıyla da bağlantılı bir biçimde şöyle açıklamaktadır;

"Bir gerçekten, on dokuzuncu yüzyılda toplumsal düzenin birçokları için bir hapishane haline geldiği, bu hapishaneden tek kaçış yolunun abartma, aşırılık ve genel olarak karikatür yoluyla olumlama olduğu gerçeğinden kaçmak olanaksızdır. Hilkat garibesi görünümündeki her şey, insanı özgürleştirebiliyordu da. Bu yüzden on dokuzuncu yüzyıl, Frankenstein'ın yaratığ Dracula gibi hilkat garibelerinin belirişine tanık olmuştur (Sanders, 2001, s.282)."

Karikatür, toplumsal bir işlevle pek çok konuda eleştirel fikirlerin yayılmasına yardımcı olmakta; insanların sözle dile getiremedikleri noktaları, çizgilerle yorumlamalarına imkân vermektedir (Çakır ve Öztekin, s. 2014).

"Muhalefet işleyişinde mizah yapmaya ihtiyacı olan toplum, 'kötü' olarak adlandırdığg iktidara gülme yoluyla direnir. Otoriteyi gülme ve alayla tehdit eder. Hegemonyanın varlığın sürdürmesinin tek yolu toplumda rizanın üretimidir. Oysa mizah, 
bu gizli senaryoyu geçersiz kılmakta ve egemenlerin ciddiyet halesini parçalamaktadır (Arık, 1998, s.121)."

$\mathrm{Bu}$ anlamda politik mizahı rahatlama kuramı çerçevesinde değerlendirmek mümkündür. Halk kendinden üstün konumda olan iktidar erklerini zayıf ve gülünç hallerde görmekten memnuniyet duyar. Bu onda rahatlama ve eşitlik hissi uyandırır. Bir anlamda haksızlığa uğramış hissetmenin ya da daha aşağı durumda olmanın intikamını alır. Diğer yandan, politik mizah ve karikatür kitlelerin öfkesini boşaltmasının ve rahatlamasının bir yolu olarak görülür ve bu nitelikleri itibariyle bir ölçüye kadar iktidarlar tarafından hoşgörülür. Mizahı kullanan kişi iktidarları sıradan insanlar seviyesine indirerek gerçek hayattaki dengesizliği giderir ve toplumsal bir işlev gösterir. İktidarların dokunulmazlığı ve ciddiyeti mizahın arkasına sığınmış eleştirilerle kırılmaya çalışılır ve büyük ölçüde başarıya ulaşılır.

\section{Batı'da Karikatürün Tarihsel Gelişimi}

"İnsan ve toplumla ilgili her tür olayı konu alarak abartılı bir biçimde veren, düşündürücü ve güldürücü resim" olarak tanımlayabileceğimiz karikatür; bu genel tanımı itibariyle insanlık tarihi kadar eski kabul edilse de gerçek anlamını Rönesans döneminde bulmuştur (Arık, 1998, s.4). Aralarında Leonardo da Vinci, Monet ve Daumier'in de bulunduğu birçok Rönesans ressamın karikatür çalışmaları mevcuttur. Ancak dönemin karikatürleri siyasi veya toplumsal hiciv amacı dışında dikkat çeken olumsuz özelliklerin abartıldığı portre çizimlerinden oluşmaktadır.

Genel kabul görmüş ilk karikatürist, Annibale Carraci'dir. (1560-1609) Bu görüşün dayandığı temel nokta ise Da Vinci'nin tanınmamış, halk içinden genç kız ya da yaşlı adam tiplemelerinin yanında Carraci'nin halk arasından tanınan bilinen kişilere ilişkin çizimleridir (http://www.encyclopedia.com/doc/1O128-caricature.html, Erişim Tarihi: 20.02.2015).

"Karikatür, Carraci kardeşlerin atölyesinde bir oyun biçiminde çıkmıştır. Portre deformasyonuna dayanan bu çizimlerde, kurbanın yüzleri hayvanlara yahut cansız nesnelere benzetilmektedir (Arık, 1998, s.4)." 
Lenn Redman, "Karikatür Nasıl Çizilir" adlı eserinde karikatürün özünün abartma olduğunu vurgulamaktadır; Redman'a göre, karikatüristler gerçeğin inkârı adına çarpıtmak yerine gerçek adına abartırlar (http://www.aboutfacesentertainment.com/pages/caricature-history.html, Erişim Tarihi: 12.03.2016).

"Aydınlanmanın bir ürünü olan karikatür, İtalya'da Rönesans'la birlikte doğdu. O çă̆daki adı, hücum etmek anlamina gelen 'Caricare' idi. Zamanla gelişerek günümüze dek ulaştı. 'Hücum etmek' yerini 'eleştiri'ye bıraktı. Onun için bu sanatta dalkavukluğun yeri yoktur. Amacı ya sanatsal boyutlara ulaşmak ya da mizahi eleştiri yoluyla toplumları iyiye, doğruya yönlendirmektir. Gülme, güldürme tek amaç olmayıp katkısal bir unsurdur (Erçetin, 1999)."

Öngören'e göre karikatürde iki mizah öğesi izlenebilmektedir; birincisi insanın yüz ya da gövde oranını farklılaştırarak sıradışı görüntüler elde etmek ikincisi ise iki farklı türü -örneğin bir insan başı ile bir at gövdesinibirleştirerek mizahı sağlamak eğilimidir(1983)."

Kamunun desteğiyle kamusal bir görev ifa ettiği varsayılan gazeteciliğin mizahla birleştiği en keskin noktayı ise günümüzde karikatürler oluşturmaktadır. Bir başka deyişle, karikatür, mizahın sanat ve gazeteciliğin kesiştiği noktada yer almaktadır. Gazetecilerin elindeki masum görünüşlü bu silah, sadeliği ve kolay anlaşılır haliyle aynı zamanda en etkin olanıdır. Gazeteci, karikatürle mizahı kullanarak ispat yükümlülüğü taşımadan, geniş kitleleri kendi düşüncesinde ikna edebilir; bunun için ayrıntılı açılamalara girmesi ya da düşüncelerini ispat etmesi gerekli değildir. Karikatür, zaten "abartı"dan oluşmaktadır ve doğruluk iddiası taşımaz. Bununla birlikte, ilk bakıştaki iddiasız görünümüne karşılık karikatür, tarih boyunca halk üzerindeki etkisinin farkında olan siyasi iktidarların korktukları ve engellemeye çalıştıkları bir araç olmuştur.

17. yy.da soyluların eğlencesi olarak ortaya çıkan karikatür, özellikle William Hogarth'ın salt çarpitılmış insan görüntüleri yerne davranışlardaki çelişkileri ortaya koyan oyma baskılarıyla farklı bir boyut kazanmıştır (Arık, 1998, s.5). Bir başka deyişle karikatür bu dönemden sonra gerek biçimsel gerekse içerik olarak günümüzdeki şeklini almış; sosyal ve siyasi hiciv işlevini edinmiştir. 
Toplumun o dönemine ait siyasi ve sosyal hayatına ilişkin basit göndermeler içeren karikatür, çoğu zaman kendi döneminin dışına çıktığında anlamını ve vermek istediği mesajı yitirmektedir. Ancak bununla birlikte, dönemin siyasi ve sosyal hayatı bağlamında değerlendirilmesi gereken karikatürün söz konusu döneme ışık tutan bir ayna olduğu da göz önünde bulundurulmalıdır.

\section{“Yaratma Hakkı” ve İfade Özgürlüğü Çerçevesinde Karikatür}

Karikatür, bir ifade biçimidir ve ifade özgürlügü kapsamında değerlendirilmelidir. Nitekim 09.06.2004 tarihli ve 5187 sayılı Basın Kanunu, 3. maddesinde; "Basın özgürdür. Bu özgürlük; bilgi edinme, yayma, eleştirme, yorumlama ve eser yaratma haklarını içerir." demek suretiyle genel kabul görmüş haklara bir de yaratma hakkını eklemiştir ve karikatür de yaratma hakkı çerçevesinde kendine yer bulmaktadır. Ancak yaratma hakkı, söz konusu özgürlük çerçevesinde kullanıldığı takdirde sınırsız olmayacak; basın özgürlügü gibi çeşitli sınırlamalara tabi tutulacaktır. Bununla birlikte basın özgürlügünden farklı olarak karikatür vasıtasıyla kullanılan ifade özgürlügünün sanatsal bir boyutu da olmaktadir.

Basın- günümüzdeki geniş anlamıyla medya- açısından iktidara karşı gösterilen yakınlığın mizah dergilerinde ve mizahçılarda görülmemesi ya da nadir görülmesi ilginç bir nokta olarak kaşımıza çıkmaktadır. Nitekim Hasan Seçkin, bir röportajında iktidar-mizah ilişkilerini şöyle açıklamaktadır;

"İktidar mizahı seomez. Çünkü ondaki dil ve kendine özgü muhalefet iktidarm işine gelmez. Bu ülkede yaşanulan yalan, talan ve baskılara karşı en güçlü muhalefeti karikatür/mizah sanatı gösteriyor desek abartı olmayacaktır. Ancak, ülkemizde saygı duyulan birçok karikatür ustası olmasına ră̆men, bu çizgi sanatının istenilen seviyeye ulaştığı söylenemez. Nedenine gelecek olursak: Basında fazla yer bulamıyor, sadece mizah dergilerinin varlı̆̆ bu anlamda bir şans. Dünya ülkeleri ile kıyaslandığında, karikatüre verilen önem ve değer çok yetersiz. Karikatürde genç ve yetenek 
yüklü bir kuşağın geldiğini de inkâr etmemeliyiz; özellikle Gezi sürecinde bunu gördük (https://www.birgun.net/haber-detay/iktidarmizah-sevmez-64772.html, Erişim Tarihi: 02.03.2018)."

Seçkin'in üzerinde durduğu, karikatürün basında yeterince yer bulamayarak çoğunlukla bağımsız mizah dergilerinde kendine yer bulması, bir yandan gelişimini engellemekle beraber diğer taraftan, karikatüristlerin gazetecilere görece bağımsızlıklarını korumalarını sağlamıştır. Nitekim günümüzde karikatüristlerin bağlı bulundukları kuruluşların mevcut iktidarla olan ekonomik ilişkilerden temellenen otosansür kaygıları yoktur. Mizah dergilerinin önündeki temel engel ise çoğunlukla açılan yüklü tazminat davaları ve bir örneğini geçtiğimiz yıllarda Charlie Hebdo dergisine yönelik yaşadığımız tehdit ve şiddet içerikli saldırılardır.

Gerek Türkiye coğrafyasındaki tarihsel sürecine gerekse günümüzdeki karikatür savaşlarına ve karikatüristlere açılan davalara baktığımızda karikatürün salt bir sanat dalı, özel yeteneğe bağlı bir meslek değil; özgün bir ifade biçimi olduğu açıkça görülmektedir. Nitekim mizah, ülkemizde ifade özgürlüğünün en etkin ve güçlü silahı olarak karşımıza çıkmaktadır. Öyle ki basın özgürlüğünün medya ve iktidar arasındaki ekonomik ilişkilere kurban verildiği ve medya kuruluşlarının oligopolleşerek hüküm sürdügü günümüz şartlarında, görece küçük ölçekleri ve görece bağımsız karakterleriyle mizah dergileri, ifade özgürlüğü savaşına ve muhalefet hakkını kullanmaya devam etmektedirler. Değişen tek husus, muhalif gazetecilerin azaldığı bu dönemde karikatüristlerin daha fazla göz önünde olmasıdır.

"Mizahın esnekliği, kıvraklığı, mizahçının toplumsal değişimi ânında kavramasını ve aktarabilmesini sağlar. Mizahçının sosyal bilimci karşısındaki üstünlü̈̆̈̈̈, değişimi güçlü bir sezgiyle kavrama ve ânında tepki göstererek mizah formunda kamusal alana aktarma yeteneğinde saklıdır. Bu noktada, yeni kuşağın "hoca" ve üstatlarının öncelikle mizahçılar olduğu söylenebilir (Cem Yılmaz, Metin Üstündă̆, Mehmet Çă̆ģă̆g, Bahadır Baruter, Yiğit Özgür, Tuncay Akgün vb.). Bu olgu, şaşırtıcı olmamalıdır. Çünkü mizah, tüm sanatlar arasında "geneli gözetleyen" tek sanattır. Mizahçının 
metodu dışa dönüktür, genelleşebilir neticeler gözetir, dağınık verileri birbirine yaklaştırır, benzer halleri karşılaştırarak müşterek "garabetler" seçer ve bunları eserlerine aktarı (http://www.eskop.com/skopbulten/\%E2\%80\%9Cutopya-acligi\%E2\%80\%9Dolarak-gezinin-mizahi/1719, Erişim Tarihi: 19.02.2016)."

Eleştiri, mizahın özellikle de karikatür sanatının doğasında vardır. Gerek siyasi yaşam açısından gerekse sosyo-ekonomik açıdan bakıldığında, mizahçının yaşanılan ortamı "onaylama", ya da "yüceltme" şansı yoktur. Onun görevi, hangi açıdan olursa olsun toplumdaki çarpıklıkları işaret etmek ve güldürü sanatının desteğiyle insanları bunlar üzerine düşünmeye davet etmektir.

Türkiye, Haziran 2014'te Cumhuriyet tarihinin ilk sivil itaatsizlik eylemi ile birlikte 80 'lerin apolitikleşme sürecinden soyutlanmayı başaran ve "90 kuşağı" olarak nitelenen gençlerin beklenmeyen tepkileriyle tanıştı. Gezi Parkı eylemleri olarak anılan bu olay ülkemizde ciddiyetle özdeşleşmiş kabul edilen siyasete karşı yoğun mizah içeren bir muhalefeti de beraberinde getirmiştir. Sosyal medya aracılığıyla görece geniş bir kesime yayılan bu paylaşımlar, kanımızca ülkemizde mizah içeren bir muhalefetin gücünü göstermesi açısından anlamlıdır.

Web 2.0'in olanak verdiği etkileşim, sosyal medya olarak adlandırdığımız yeni bir medya türünün ortaya çıkmasına neden olmakla birlikte, kişiler ve statüler arasındaki mesafeyi yok etmiş; siyasetin ve siyasetçinin toplumun üzerinde konumlanması önünde önemli bir engel teşkil etmeye başlamıştır.

Türk siyaset tarihine baktığımızda siyaset, siyasetçi ve mizah arasında keskin bir ayrım görülmektedir. Özellikle cumhuriyet tarihi boyunca mizah, genel olarak muhalif yapısını korurken, hoşgörü sınırları açısından farklılaşan siyasi iktidarlar ise tüm ciddiyetleriyle mizahın oldukça uzağında konumlanmıştır.

Son yıllarda sosyal medya kullanımının artması ve yurttaş gazeteciliğinin Twitter gazeteciline doğru geçirdiği dönüşümle, gazetecisiyasetçi ve sıradan internet kullanıcısı arasında iletişim açısından görece bir eşitlik sağlanmış; bir noktada mizahın da katılımıyla siyasetin ciddi yüzü önemli bir kırılmaya uğramıştır. 
Gezi Olayları olarak bilinen Türkiye'nin ilk sivil itaatsizlik eyleminde en çarpıcı biçimde gündeme gelen "sıradan vatandaşın mizah aracılığıyla muhalefeti", sosyal medya alanında karşımıza çıkmakta; görece kullanıcı eşitliği ve etkileşim özelliğiyle hedef alınan siyasilerin de aynı dili kullanarak cevap vermesine olanak tanımaktadır.

Türkiye'de Cumhuriyetin ilanından sonra en keskin ve sistemli biçimde Markopaşa'yla başlayan ve Gırgır'la devam eden "karikatürün siyasi iktidara karşı savaşı" nın günümüzde muhalif duruşları ve haftalık tirajları göz önünde bulundurulduğunda, Uykusuz ve Leman dergileriyle devam ettiğini söylemek mümkündür.

1985 'ten sonra Girgır'dan ayrilan bir ekip tarafından kurulan Limon dergisinin 1991'de kapanmasından sonra aynı ekip tarafından kurulan Leman dergisi günümüzde yoğun tehdit ve baskılara, açılan davalara karşın yayın hayatına devam etmektedir.

"Gırgır ve sonrasındaki benzeri bütün mizah dergileri (Limon da dâhil olmak üzere) büyük bir medya kuruluşuna aitken Leman dergisi Mehmet Çağçağ ve Tuncay Akgün ortaklığında bağımsız bir dergi olarak kuruldu. $\mathrm{Bu}$ yönüyle kendisinden sonra gelen mizah dergileri için (Penguen, Uykusuz ve CafCaf gibi) de model oldu (http://tr.wikipedia.org/wiki/Leman, Erişim Tarihi: 19.02.2015). Leman'ın ve sonrasında aynı yolu izleyen mizah dergilerinin küçük ölçekli yapıları, bir yandan geniş kitlelere ulaşımının önünde bir engel oluştururken diğer yandan, korumaya çalıştığı görece bağımsız yapısıyla okuyucu kitlesi üzerindeki etkisini arttırmaktadır.

\section{Bir İfade Biçimi Olarak Karikatüre Yönelik Sınırlama ve Müdahaleler}

Genel olarak yaratma hakkı sınırsızdır. Ancak basın özgürlüğü içerisinde yer alan "yaratma hakkı" nın bir takım sinırlamaları vardır. Bu noktada karikatürün iki özelliği üzerinde durulmasında fayda görülmektedir. Birincisi karikatür bir sanat eseridir. Sanatsal bir yetenek ve emek gerektirir. İkincisi ise karikatür, bir ifade biçimidir. Sanatçı, karikatür vasıtasıyla ifade özgürlüğü çerçevesinde eleştiri hakkını kullanır ve eserini çoğunlukla basin vasitasiyla kamuya sunar. Yaratma hakkı, bu noktada basın özgürlügünün koruması altına girmekte ve söz konusu özgürlüğün içerdiği haklardan faydalanmaktadır. Diğer taraftan da yine bu noktada, karikatür yaratma hakkının sınırsız özgürlüğünden çıkmakta ve basın 
özgürlüğünün yasal sınırlama nedenlerine tabi olmaktadır. Ancak bu meşru sınırlamalar, geniş yorumlanarak karikatüristin ifade özgürlüğünü kısıtlayacak uygulamalara neden olabildiği gibi uzun yargilama süreçleri ve dava giderleri de karikatüristte bıkkınlık yaratarak otosansüre neden olabilmektedir.

Diğer taraftan, karikatüristlerin karşılaştığı sınırlamalar salt yasal sinırlamalardan ibaret değildir. Ülkemizde ve dünyada örneklerini gördüğümüz üzere tehdit ve fiziksel saldırı da günümüzde özellikle muhalif ve aykırı duruş sergileyen karikatüristlerin sıkça karşılaştığı müdahalelerin başında yer almaktadır.

İfade özgürlüğü, Avrupa İnsan Hakları Sözleşmesi'nin 10. maddesinde düzenlenmiştir. Söz konusu maddeye göre;

1. Herkes ifade özgürlüğ̈̈ hakkına sahiptir. Bu hak, kamu makamlarının müdahalesi olmaksızın ve ülke sinırlarn gözetilmeksizin, kanaat özgürlüğünü ve haber ve görüş alma ve de verme özgürlüğ̈̈nü de kapsar. Bu madde, Devletlerin radyo, televizyon ve sinema işletmelerini bir izin rejimine tabi tutmalarına engel değildir.

2. Görev ve sorumluluklar da yükleyen bu özgürlüklerin kullanılması, yasayla öngörülen ve demokratik bir toplumda ulusal güvenliğin, toprak bütünlüğ̈̈nün veya kamu güvenliğinin korunması, kamu düzeninin sağlanması ve suç işlenmesinin önlenmesi, sağlı̆̆ın veya ahlakın, başkalarının şöhret ve haklarının korunması, gizli bilgilerin yayılmasının önlenmesi veya yargı erkinin yetki ve tarafsızlı̆̆ııın güvence altına alınması için gerekli olan bazı formaliteler, koşullar, sinırlamalar veya yaptırımlara tabi tutulabilir.

Basın özgürlügüne getirilen ve temelini Avrupa İnsan Hakları Sözleşmesi'nin 10 maddesi ikinci fıkrasından alan sınırlamalar, bütün demokratik sistemlerde Anayasalarca belirtilmiştir. Karikatür bu yasal sinırlamaların hepsine tabi olmakla birlikte, uygulamada en çok sorun oluşturan sınırlamalar özetle; hakaret, devletin korunması, müstehcenlik ve dini değerleri aşağılama olarak sıralanabilir. 


\section{Hakaret}

Ülkemizde karikatüristlerin yargılandığı maddelerin başında 5237 Sayılı Türk Ceza Kanunu'nun 125. maddesi gelmektedir. Hakaret başlıklı söz konusu maddenin 1. fikrasina göre, "Bir kimseye onur, şeref ve saygınlığını rencide edebilecek nitelikte somut bir fiil veya olgu isnat eden veya sövmek suretiyle bir kimsenin onur, şeref ve saygınlığına saldıran kişi, üç aydan iki yıla kadar hapis veya adlî para cezası ile cezalandırılır. Mağdurun gıyabında hakaretin cezalandırılabilmesi için fiilin en az üç kişiyle ihtilat ederek işlenmesi gerekir." Maddenin 2. fıkrası, fiilin sesli, yazılı veya görüntülü bir iletiyle işlenmesi halini; üçüncü fıkranın a bendi ise hakaretin "kamu görevlisine karşı görevinden dolayı" işlenmesi halini düzenlemektedir.

Ülkemizde özellikle iktidar mensuplarının karikatüristlere açtıkları davaların çoğu temelini yukarıdaki 125. maddeden almaktadır.

\section{TCK 301. Madde}

TCK'nın “Türklüğü, Cumhuriyeti, Devletin kurum ve organlarını aşağılama" başlıklı maddesine göre;

“(1) Türklüğ̈̈, Cumhuriyeti veya Türkiye Büyük Millet Meclisini alenen aşă̆ılayan kişi, altı aydan üç yıla kadar hapis cezası ile cezalandırılır.

(2) Türkiye Cumhuriyeti Hükûmetini, Devletin yargı organlarımı, askerî veya emniyet teşkilatını alenen aşă̆ılayan kişi, altı aydan iki yıla kadar hapis cezası ile cezalandırılır.

(3) Türklü̈̆̈̈ aşağılamanın yabancı bir ülkede bir Türk vatandaşı tarafindan işlenmesi hâlinde, verilecek ceza üçte bir oraninda artırilır."

Bununla birlikte madde, 4. fikrasıyla eleştiri amacıyla yapılan düşünce açıklamalarını kapsam dışında bırakmaktadır. Karikatüristlerin temel hedefinin iktidarlarn eleştirmek olduğu varsayılırsa en çok yasal sorun yaşadığ l kesimin de iktidarlar olması kaçınılmazdır. Bununla birlikte yukarıda anılan maddelerin geniş 
yorumlanması bir ifade biçimi olarak karikatürün sinırlandırılmasında oldukça olumsuz bir görüntü sergileyebilmektedir.

\section{Müstehcenlik}

Müstehcenlik TCK'nın 226. maddesinde düzenlenmiştir. Söz konusu maddenin 2. fıkrasına göre; "Müstehcen görüntü, yazı veya sözleri basın ve yayın yolu ile yayınlayan veya yayınlanmasına aracılık eden kişi altı aydan üç yıla kadar hapis ve beş bin güne kadar adlî para cezası ile cezalandırılır." Bununla birlikte aynı maddenin 7. fikrası "Bu madde hükümleri, bilimsel eserlerle; üçüncü fıkra hariç olmak ve çocuklara ulaşması engellenmek koşuluyla, sanatsal ve edebi değeri olan eserler hakkında uygulanmaz." demek suretiyle karikatürün de içinde yer aldığını kabul edebileceğimiz sanatsal değeri olan eserleri kapsam dişında bırakmıştır. Ancak bu noktada karşımıza neyin "müstehcen" olduğu, neyin "sanat" olduğu ve bunlara kimin karar vereceği gibi sorular çıkmaktadır.

$\mathrm{Bu}$ hususta karikatürün karşısında çıkan yasal sınırlamalardan bir diğeri, "Muzır Kanunu" olarak da bilinen 21/6/1927 tarihli ve 117 Sayılı "Küçükleri Muzır Neşriyattan Koruma Kanunu"dur. 88 yıllık tarihi olan söz konusu kanunun en son uygulamalarından biri de bir mizah dergisini hedef almıştır. Nitekim söz konusu kanun hükümleri uyarınca kurulan Başbakanlık Küçükleri Muzır Neşriyattan Koruma Kurulu'nun aldığ kararla mizah dergisi Harakiri'ye 150 bin TL ceza kesilmiş ve ilk defa bir mizah dergisi "siyah poşet" içinde satılmaya başlanmıştır. Ancak cezanın ağırlığına fazla dayanamayan dergi, yayın hayatına başladıktan sadece iki ay sonra kapanma kararı almıştır.

Başbakanlık Küçükleri Muzır Neşriyattan Koruma Kurulunun konuya ilişkin verdiği cezanın gerekçeleri ise şunlardır (http://www.ntv.com.tr/arsiv/id/25365256/, Erişim Tarihi: 26.05.2015);

- İnsanları evlilik dışı ilişkiye özendirmek.

- Türk halkını tembellik ve maceraperestliğe itmek. 


\section{Dini Değerleri Aşağılama}

"Dini değerleri aşağılama, dini nedenlerle toplumun bir kesimini düşmanlığa tahrik suçu" TCK'nın 216. maddesinde, "dini nedenlerle hakaret" suçu da 125. maddesinde ayrı ayrı düzenlenmektedir. Her iki maddede de bu suçların alt sınırı 6 ay, üst sınırı ise 3 yıl hapis cezası olarak belirlenmiştir.

Kişisel bir inanç ve vicdan özgürlüğü olması yanında dinin, toplumsal yaşamda önemi tartışılmaz bir durumdadır. Ancak ülkemiz gibi, İslam dinini laiklik ilkesi ile bağdaştırmaya çalışan toplumlarda bile dini iktidarın diğer iktidar türlerinden farklı tutularak karikatüristlerin ve mizahçıların konusunun dışında bırakılması mümkün görünmemektedir. Bu noktada mizah unsuru hususun inançlardan ziyade inancı kullananlar olduğu da unutulmamalıdır.

Ülkemizde bu konuda açılan davalar görece az sayıda olmakla birlikte toplumun dini değerlere olan hassasiyetini göstermesi açısından anlamlıdır. Nitekim Penguen'de çizdiği karikatürde cami duvarına "Allah yok, din yalan" yazan Penguen dergisi çizeri Bahadır Baruter, "Halkın bir kesiminin benimsediği dinî değerleri alenen aşağılama" suçundan 1 yıl hapis istemiyle yargılanmaktadır (http://www.aktifhaber.com/skandal-karikatur-icin-1-yil-hapis-498008h.htm, Erişim Tarihi: 26.05.2016).

Bununla birlikte, Avrupa'da $\mathrm{Hz}$ Muhammed'in karikatürlerinin yayınlanmasına ilişkin çıkan krizler yansımasını doğal olarak Türkiye'de de bulmuştur. Nitekim Charlie Hebdo dergisine yapılan saldırının ardından Hz. Muhammed karikatürlerine sayfalarında yer veren Cumhuriyet gazetesi yazarları Ceyda Karan ve Hikmet Çetinkaya hakkında 4,5 yıla kadar hapis istemiyle iddianame düzenlenmiştir (http://www.sabah.com.tr/gundem/2015/04/08/karan-ve-cetinkayaya-charlie-hebdo-davasi. Erişim Tarihi: 08.04.2015). Soruşturmaya iki gazeteciden şikâyetçi olan 1280 kişinin dilekçeleri de dâhil edilmiştir.

\section{Son Dönem Karikatür Davaları}

En genel anlamıyla baktığımızda demokrasi, siyasi iktidar ve toplumun diyalog içinde bulundukları yönetim biçimidir (Akad, 1976, s.24). Ancak 
bu ilişki liberal demokrasiyle yönetilen her ülkede farklı boyutlarda tezahür etmektedir. Bir diğer deyişle kişisel hak ve özgürlüklerle özdeşleştirdiğimiz demokrasinin bir ülkede nasıl uygulanacağı; toplum ve siyasi iktidarlar arasındaki ilişki dengesiyle ve bu dengeyi oluşturan tarihi, kültürel, ekonomik, dini ve siyasi alt yapıyla doğrudan ilintilidir. Benzer şekilde, söz konusu ülkede ifade özgürlüğüne bakışı da yukarıda saydığımız öğeler bir araya gelerek belirleyecektir.

Dengenin özgürlükler ve toplumsal vicdan aleyhinde bozulduğu durumlar ise beraberinde güçlü bir muhalefeti getirmektedir. Gerek tarihsel açıdan değerlendirdiğimizde gerekse geçtiğimiz yıllarda ülke gündemini değerlendirdiğimizde, mizahın ve karikatürün en etkili olduğu dönemlerin baskı unsurunun arttırıldığı dönemler olduğu görülmektedir.

Ülkemizde karikatür, doğuşundan itibaren güçlü ve etkili bir muhalefet aracı olmuş ve bu nitelikleri itibariyle iktidardaki güçler tarafından baskı altına alınmaya çalışılmıştır. Tarihsel sürece bakıldığında da özellikle toplumda ekonomik ve sosyal bir gerilemenin bozulmanın meydana geldiği durumlarda hem mizahın ve karikatürün hem de onlara uygulanan baskının arttığı görülmektedir.

Ülkemizde 2004 yılından itibaren gerek Basın Kanunu gerekse Türk Ceza Kanunu değişmiş; ifade özgürlüğü ile çelişen maddeler kaldırılarak "demokratikleşme" yoluna gidilmiştir. Ancak kanun maddeleri üzerinde gerçekleştirilen bu iyileştirmenin açılan davaların sayısında bir azalma meydana getirdiğini söylemek mümkün gözükmemektedir. Nitekim Leman ve Penguen dergilerine açılan davalar, Cumhuriyet gazetesinin iki yazarına Charli Hepdo dergisinin karikatürlerine köşelerinde yer verilmesi nedeniyle ikişer yıl hapis cezasının verilmesi, karikatüristlerin neredeyse tamamının tazminat davalarına ilişkin çekinceleri nedeniyle otosansür uyguladıklarına ilişkin söylemleri ve buna rağmen muhalif çizgide yer alan neredeyse bütün karikatüristlerin açılmış davalarının olması bunun önemli bir göstergesidir.

AKP Hükümetleri döneminde basına yansıyan ilk karikatür davası dönemin Başbakanı Recep Tayyip Erdoğan ve Danışmanı Cüneyt Zapsu tarafından Evrensel Gazetesi çizeri Sefer Selvi'ye açılmıştır. Dava konusunu, 5 Nisan 2004'te Evrensel Gazetesi'nde yer alan Cüneyt Zapsu'nun Başbakan'ın sırtında; ipleri elinde tutarken karikatürize edilmesi oluşturmaktadır. 
Yargitay tarafından bozulan ceza kararında cezanın nedeni olarak "karikatürün estetik olmaması ve etik kuralları çiğnemesi” gösterilmiştir. Ancak bu noktada sanatsal bir içerik taşıyıp taşımamanın ötesinde karikatürün estetik değerinin mahkeme tarafından belirlenebilecek bir husus olarak görülmesi de tartışmalıdır. Daha önce ifade ettiğimiz gibi diğer sanat biçimleri gibi mizahın ve karikatürün de ifade özgürlüğü kapsamında değerlendirilmesi sanatsal bir değer taşıyı taşımaması ile gerçekleşmektedir. Ancak sanatçının sanatını icra ederek elde ettiği ürünün estetik değerinin sorgulanması hukuk davalarının konusunu oluşturmamalıdır.

Söz konusu dönemde uzun süre tartışılan davalardan biri de Cüneyt Zapsu tarafından çizilen; dönemin Başbakan'ı Erdoğan'ın yumağa dolanmış bir kedi olarak resmedildiği ve İmam Hatip Liseleri ile ilgili sorunda içine düşülen çıkmazın karikatürize edildiği kedi karikatürüdür. 9 Mart 2004'te Cumhuriyet Gazetesi Çizeri Musa Kart tarafından çizilen karikatür için, Erdoğan tarafından açılan davanın esasını, dönemin başbakanının bir kediye benzetilerek "kişilik haklarına saldırı" gerçekleştirildiği iddiası oluşturmaktadır. Ancak karikatür sanatının temelinde birebir resmetme değil; abartma, gülünç kısımların ön plana çıkarılması ve benzetme vardır; Turgut Çeviker, söz konusu davayı ve karikatürün temel özünü şöyle ifade etmiştir;

"Geçmiş dönemlerde de liderler hayvanlara benzetilmiştir; ancak Erdoğan, kedi olarak çizilmeyi kabul etmemiş, çizerine dava açmıştır. Benzetme sanatı, karikatürcünün elinden alınamaz. Bunun gerçekleşmesi, karikatürcünün tırnaklarının sökülmesi anlamına gelir. Karikatürcü, buna izin vermez, veremez; çünkü onun işi 'benzetmek'tir! Erdoğan, genel olarak sanattan, özel olarak da mizahtan anlamıyor ve de hoşlanmıyor. Karikatürcüler, siyasetçiler tarafindan mahkemeye veriliyor. Muhalefet de iktidar partisini eleştiren karikatürleri seviyor. Gırgır'ın uzantısı olan bugünkü mizah dergileri, AKP iktidarlarna karşı çok sert bir muhalefet yaptı, yapmaya da devam ediyor. Ancak Leman, Penguen ve Uykusuz, gündelik eleştiriyi cesurca yapsalar da bu, büyük yapitlar ortaya koydukları anlamina gelmez (https://www.haberturk.com/kultur- 
sanat/haber/602893-turkiyenin-karikaturle-imtihani, Erişim Tarihi: 12.12.2018)."

Musa Kart'a açlan dava, Penguen dergisinin sekiz çizerinin tepkisiyle karşılanmış; dergi bir sonraki sayısını Erdoğan'ın farklı hayvanlar şeklinde karikatürize edildiği “Tayyipler Âlemi” başlıklı bir kapakla sunmuştur. Açık bir meydan okuma içeren bu tavır, muhalif duruş sergileyen çizerlerin eleştiri haklarını sonuna kadar savunmakta kararlı olduklarını göstermektedir.

Yukarıda özetlediğimiz iki dava da önce Asliye Hukuk Mahkemelerince kabul edilmiş, ancak ilki beş ikincisi kırk bin liralık manevi tazminat talepleri, iki yıl süren davalar sonucunda Yargitay tarafından bozulmuştur.

Yayınlandığı ve davaların sürdüğü dönemde oldukça ses getiren karikatürlere karşı, Karikatürist Hatice Meryem'in “Sürpriz olmadı. Biz daha fazlasını hesap etmiştik. Madem parasıyladır, o zaman cezamızı öder, karikatürümüzü çizeriz dedik. Ve çizdik (http://www.gazetevatan.com/penguen-e-bir-dava-daha-49852-gundem/, Erişim Tarihi: 11.05.2016)" sözleri, karikatüristler açısından eleştiri özgürlüğünün bir bedeli olduğunun ve çoğu karikatüristin bu bedelin farkında olarak söz konusu hakkı kullandığının bir göstergesidir.

Musa Kart ve Cumhurbaşkanı Erdoğan arasındaki hakaret davalarından bir diğeri ise 17 Aralık yolsuzluk ve rüşvet iddiaları sürecinde gerçekleşmiştir. Erdoğan'ın söz konusu iddialar üzerine vurgu yapan bir karikatürü nedeniyle ve 10 yll hapis istemiyle "basın yoluyla hakaret" davası açtığ1 çizer Musa Kart beraat etmiştir (http://www.diken.com.tr/musa-kart-gercekleri-cizdim-dedi-erdoganin-actigi-11-aralik-davasindan-beraat-etti/, Erişim Tarihi: 11.05.2017). Musa Kart'ın “Gerçekleri çizdim" diyerek savunma yaptığı dava, sosyal medya vasıtasıyla uluslararası arenada da yankı buldu. Nitekim The Guardian'ın ünlü çizeri Martin Rowson, Twitter'da bir kampanya başlatarak, tüm çizerlerden “eğer başlarını belaya sokmayacaksa" Erdoğan'ın karikatürlerini tweet atıp kendisine bir parça alçakgönüllülük dersi vermesini istedi (http://www.diken.com.tr/dunyaca-unlu-karikaturistler-musa-kartla-dayanisma-icin-erdogana-karsi-birlesti/, Erişim Tarihi: 11.05.2017). 
Erdoğan'ın karikatür dergilerine açtığı davalar Penguen'le sınırlı kalmamıştır. 2006 yılında, bu sefer Leman dergisi, "Reco Kongo Kenesi Türkiye'nin Anasını Ağlatıyor" başlıklı kapağıyla dava konusu oldu. Derginin söz konusu kapakla yayınlanmasının ardından, Karikatürist Mehmet Çağçağ ve Leman dergisi aleyhine "Başbakanı kan emici, habis ve parazit bir hayvan olan keneye benzeten karikatürün kişilik haklarına tecavüz niteliğinde olduğu, Erdoğan'ın küçük duruma düşürülerek eleştiri sınırlarının aşıldığı" iddia edilerek 25.000 TL'lik manevi tazminat davası açılmıştır. Yargıtay'ın Ankara 14. Asliye Hukuk Mahkemesi'nin 18 Nisan 2007 tarihli "Kene de bir varlıktır, benzetme eleştiri hakkıdır" tespitinin yer aldığı gerekçeli ret kararını onamasıyla (http://www.bianet.org/bianet/ifade-ozgurlugu/106803-reco-kenesi-nden-kurtulanleman-ahlaksizlik-tan-mahkemelik, Erişim Tarihi: 11.05.2017), Erdoğan'ın karikatüristler aleyhinde açtığı tazminat davalarından biri daha ifade özgürlügü ve eleştiri hakkı lehine sonuçlanmıştır. Karikatüristler ve mizah dergileri aleyhine açılan davaların büyük çoğunluğunun ifade özgürlüğü lehine sonuçlandığı görülmektedir. Ancak bu noktada, yüklü tazminat taleplerinin ve sıkça tekrarlanan uzun yargılama süreçlerinin karikatüristler ve mizah dergileri üzerinde yarattığı baskı da göz ard1 edilmemedir.

Bununla birlikte, AKP Hükümetleri döneminde mizah dergilerine ve karikatüristlere açılan davalar arasından tazminat cezasıyla sonuçlanan örnekler de mevcuttur. Nitekim yine Leman dergisinin 2008 tarihli "Batı'nın bilimini değil, ahlaksızlığını aldık." başlıklı kapağına dava açan Erdoğan, söz konusu davada mahkemenin derginin kapağına kaynaklık eden fotoğrafın fotomontaj olduğu ve başbakanın kişilik haklarına saldırı niteliği taşıdığı gerekçesiyle 4 bin TL tazminat almaya hak kazanmıştır (Özocak, 2011, s.287-290). Bu noktada, Yargının karikatür davalarında, söz konusu çizimin taşıdığı mesajı esas aldığı ve eleştiri hakkı sınırları içinde olup olmadığını basın özgürlüğünün içerdiği temel haklar çerçevesinde değerlendirdiği görülmektedir.

Son dönemde görülen önemli karikatür davalarından biri de Cem Safcıer isimli bir vatandaşın Cumhurbaşkanı Erdoğan'a hakaret edildiği gerekçesiyle Penguen dergisi çizerlerine açtığı davadır (http://www.cumhuriyet.com.tr/haber/turkiye/235611/Penguen_in_ka-

pagina_7_bin_TL_ceza.html, Erişim Tarihi: 25.03.2017). Erdoğan'ın da 
avukatı aracılığıyla katılma talebinde bulunarak taraf olduğu dava sonucunda, Penguen dergisi çizerleri yedi bin TL adli para cezasına mahkûm olmuştur. 21 Ağustos 2014 tarihli karikatürde, davanın esasını Erdoğan'ın karşısında ceketi iliklerken çizilen adamın elinin "yuvarlak' olması ve Erdoğan'a eşcinsel iması yapıldığı iddiası oluşturmaktadır. Erdoğan'ın Cumhurbaşkanlığı seçimlerinden sonra kendisini Dolmabahçe Sarayı'nın kapısında karşılayan görevliye "Böyle kuru kuru olur mu yaaa, en azından bir gasteci kesseydik!" cevabını verdiği karikatürde, söz konusu karikatürün özünü oluşturan eleştiri görmezden gelinerek, kastın ispatlanmasının mümkün olmadığı bir ayrıntının üzerinde durulduğu görülmektedir.

Nitekim İstanbul Barosu'nun verilerine göre; Erdoğan, Ağustos 2014 Cumhurbaşkanı seçilmesinden bu yana aralarında gazeteci ve karikatüristlerin bulunduğu 80'den fazla kişi hakkında hakaret davası açmıştır (http://www0.sondakika.com/haber/haber-turkiye-de-karikaturistlere-hapis-cezasi-7116710/, Erişim Tarihi: 11.05.2017). Bununla birlikte, ne yazık ki mizah dergilerinin sorunları; yasal sınırlamalar, tazminat talepleri ve yargı masrafları ile sinırlı kalmamaktadır. Nitekim Leman Dergisi Yazı İşleri Müdürü Zafer Aknar, dönemin Başbakanı Erdoğan'ın açtığı tazminat davalarının birinin ardından "bu nedenle çok sayıda "ağza alınmayacak küfürlü" ve tehdit içeren telefonlar aldıklarını ve hedef gösterildiklerini" açıklamıştır (http://bianet.org/bianet/bianet/105021-basbakanin-dava-actigi-leman-dergisine-kufur-ve-tehdit, Erişim Tarihi: 02.03.2018).

Ülkemizde mizah dergilerine ve karikatüristlere yönelik davalar sadece hakaret davalarından oluşmamakta; dini değerleri aşağılama, müstehcenlik ve 301. madde gibi TCK kapsamında suç olarak düzenlenen diğer unsurlar da mizah dergilerinin yasal yaptırımlar ya da tehdit ve baskıyla karşılaşmasına neden olabilmektedir.

Bununla birlikte Özocak, Türkiye'nin Karikatür ve mizah tarihini, bir nevi baskı, sansür, tahammülsüzlük ve yaptırımlar tarihi olarak tanımlamaktadır (Özocak, 2011, s.286). Kültürümüzde de önemli bir yer tutan mizah gerek Osmanlı döneminde gerekse Cumhuriyet tarihi boyunca sürekli dizginlenmeye baskı ve denetim altında tutulmaya çalışılmıştır. 
"Tarih boyunca, dünyanin her yerinde mizah ile siyaset sürekli ilişki içerisindedir. Siyaset mizahı besleyen ana damarlarn en önemlilerinden biridir. Ülkemizde bu etkileşim daha da yoğun bir şekilde gerçekleşmekte, hatta bizde mizah 'her tanımlamanın da önünde', yönetimle halk arasındaki ilişkide, halkın can simitlerinden biri olmuştur (Arık, 2002, s.90)."

Her dönem baskı ve sansürle karşılaşsa ve bazı durumlarda eleştiri sınırlarını aşsa da karikatür, Türkiye'de bütün canlılığıyla ve mizahın gücüyle ayakta durmaya devam etmektedir. Günümüzde halen yayına devam eden Leman, Uykusuz gibi mizah dergileri bunun en önemli göstergesidir.

Bununla birlikte mizah dergilerinin günümüzde sayıca oldukça azaldığı da görülmektedir. Son olarak geçtiğimiz 2017 yılının Nisan ayında Penguen dergisi de bir duyuruyla dört sayı daha çıkararak basılı yayın hayatlarına son vereceklerini bildirmişlerdir. Penguen dergisi internet sitelerinde yayınladıkları mesajla bir anlamda Türkiye'deki mizah dergilerinin ortak sorunların ortaya koymaktadır.

Söz konusu mesajda artık basılı dergi okuma alışkanlığımızı kaybettiğimizi ifade eden dergi çizerleri "Basın dünyada küçülüyor dedik, ama bizim memlekette işler biraz daha zor. Özgürlük alanı gittikçe daralırken gazetecilerin işi zorlaşıyor, mizahçıların da işi kolaylaşmıyor. Biz yine de bu ortamda kendimizce nefes olmaya çalıştık. Sevdiğimiz dergimizi de sevdiğimiz şekilde yapmak istiyoruz. Hayal ettiğimiz kalitede yapamayacaksak da yapmamayı tercih ediyoruz." ifadeleriyle okuyucularına veda etmiştir (http://www.haberturk.com/kultursanat/haber/1474710-penguen-dergisi-kapanma-nedenini-takipcileriylepaylasti, Erişim Tarihi: 21.03.2018).

\section{Batı'da Karikatüre ve Karikatüriste Müdahaleler}

İfade özgürlügüne yönelik kısttlamalar, her ülkede, söz konusu ülkenin tarihine, kültürüne, eğitim düzeylerine, inanç ve değer yargılarına göre şekillenmekte ve temel esasları teoride genel kabul görmekle beraber; uygulamada çeşitli farklılıklara rastlanabilmektedir. Nitekim ülkemizde "kişilik haklarına hakaret" çerçevesinde şekillenen karikatür davaları, 
Avrupa'da karşımıza dini değerlere hakaret şeklinde çıkmakta, Avrupa ülkelerinde yayınlanan, Hz. Muhammed'in tasvirine dayanan karikatürler, özellikle İslam ülkeleri ve Müslüman halk tarafından tepkiyle karşılaşabilmektedir.

Halen tartışma konusu olmaya devam eden ve yasal tepkiler dışında yasa dışı müdahalelere de maruz kalan söz konusu karikatür krizlerinin iki boyutu olduğunu söylemek mümkündür. Bu noktada, karikatürlerin İslam dininde yasaklanmış bir biçimde Hz. Muhammed'in yüzünü göstermesini "dini değerlerin korunması" başlı̆̆ı altında değerlendirmek mümkünken, İslam dinini terör olgusuyla özdeşleştiren karikatürlerin ise nefret söylemi ürettiği söylenebilmektedir.

\section{Danimarka Karikatür Krizi}

30 Eylül 2005'te Danimarka' da Jyllands-Posten gazetesi tarafından Hz. Muhammed'in 12 karikatürünün yayınlanması ve sonrasında özellikle $\mathrm{Hz}$. Muhammed'in yüzünün tasvir edilip edilmeyeceğine ilişkin tartışma, protesto ve saldırıların yaratığı krizdir. Karşılaşılan tepkiye Danimarkalı devlet yetkililerin özür dilemeyi kabul etmemesiyle birlikte söz konusu infial, küresel tabanda bir krize dönüşmüştür. Çoğu Orta Doğu'da olmak üzere dünyanın birçok ülkesindeki Danimarka Büyükelçilikleri saldırıya uğramış ve 2006 yılı boyunca 241 kişi hayatını kaybetmiş; 790 kişi de yaralanmıştır (http://www.aktifhaber.com/danimarkali-bakandan-karikaturitirafi-891776h.htm, Erişim Tarihi: 22.05.2017).

Özellikle Ortadoğu ülkelerince tepkiyle karşılanan bu durum halen tartışma konusu olarak yerini korumaktadır.

\section{Charlie Hebdo Dergisine Yapılan Saldırı}

Fransa'da yayınlanan haftalık mizah dergisi Charlie Hebdo, sol görüşü ve çoğunlukla sansasyon yaratan, sınır tanımayan karikatürleriyle tanınmaktadır. Katolik Kilisesi'yle sayısız davası olan derginin çizerleri ifade özgürlüğü lehine dini değerleri eleştirme hakkını savunmakta ve çizimlerini bu temel üzerine oturtarak birçok dinde kutsal kabul edilen değerleri gülünç şekillerde çizmekten kaçınmamaktadır. Katolik Kilisesi'yle sayısız davası süren derginin, yüzünün tasvir edilmesi yasak olan 
İslam Peygamberine yönelik çizimlere yer vermesi, Müslüman toplumlardan yoğun tepkiler almaya devam etmektedir.

Derginin genel yayın yönetmeni Stephane Charbonnier 2012'de verdiği bir röportajda bu hususta şu ifadelere yer vermişti;

"Muhammed'in Fransa'da karikatürünü çizemez miyiz? Hayır, tabii ki çizebiliriz. Fransa'da herkesin karikatürünü çizebiliriz. Bir Müslüman'ın desenlerimize gülmemesini eleştiremeyiz. Ama bize gelip de hangi yasalara uymamı gerektiğini söylememeliler. Ben Fransız yasalarına göre yaşıyorum, Kur'an'ın belirlediği yasalara göre değil (http://tr.euronews.com/2012/09/21/fransiz-basinininen-yaramazi-charlie-hebdol, Erişim Tarihi: 20.05.2017)."

Bununla birlikte, Charlie Hebdo'nun yayınlarının ifade özgürlüğü kapsamında değerlendirmeyerek eleştiren görüşler de mevcuttur. Nitekim uluslararası yazarlar kuruluşu PEN üyesi 6 yazar, Müslümanları inciten karikatürler yayımlayan Charlie Hebdo dergisine, PEN Amerika tarafından "cesaret ve ifade özgürlüğ̈̈" ödülü verilmesini, ABD'deki yıllık galaya katılmayarak protesto etmişti http://www.netgazete.com/dunya/charlie-hebdo-dergisinde-deprem-70119 Erişim Tarihi: 3 20.05.2017 ).

Charlie Hepdo'ya yapılan müdahaleler, yasal sınırlamalar çerçevesinde kalmamış; derginin Paris'teki binasına 7 Ocak 2015'te gerçekleşen silahlı saldırıda aralarında dergi editörü Stéphane Charbonnier ve 7 çizerin de bulunduğu, toplam 12 kişi hayatını kaybetmiş, 11 kişi yaralanmıştır. Saldırının ardından hayatta kalan çizerler gelecek haftanın sayısının basılacağını duyurmuş ve bir sonraki hafta bir milyon baskı ve meydan okuyan bir kapakla çıkan dergi kısa sürede tükenmiştir.

14 Şubat 2015 'te 1 milyon adet basılarak yayınlanan derginin kapağ 1 yine Hz. Muhammed'in tasvirini içermektedir. Söz konusu kapakta, Hz Muhammed, elinde "Je suis Charlie" (Ben Charlie'yim) yazan bir pankart tutmakta ve başlıkta "Her şey affedildi" ifadelerine yere verilmektedir.

Charlie Hebdo örneği dini değerlerin korunması başlığı altında ifade özgürlügüne yapılabilecek meşru sınırlamaların sınırları konusunda açık bir tartışmayı da tekrar gündeme getirmektedir. Bu noktada, belli bir dinin mensuplarını aşağılayan, küçük düşüren, genellemelere iterek İslamafobi yaratan ifadelerin dini değerlerin korunmasının dişında nefret 
söylemi üretmesi bakımından da yasal sınırlamalarla karşılaşması makul görülmektedir. Bununla birlikte, uluslararası bağlayıcılığı olan Avrupa İnsan Hakları Mahkemesi, Otto-Preminger İnstitut kararı yasal uygulamaları göstermesi açısından anlamlıdır. Söz konusu davanın konusunu Roman-Katolik dinine ağır eleştiriler içeren ve Tanrı, İsa ve Meryem'i inananların rencide olabileceği gülünç hallerde gösteren "Cennet Konsülü" adlı filmin gösterime girmesi oluşturmaktadır. Inssbuck Piskoposluğu bu durum üzerine suç duyurusunda bulunmuş ve savcılık tarafından filme el konulmuştur. Başvurucu aleyhinde karar verilen davada AİHM, görüşlerini şöyle ifade etmiştir;

"AİHM, Katolik dininin Torol halkının ezici çoğunluğunun dini olduğu gerçeğini görmezlikten gelemez. Avusturya otoriteleri filme el koyarken bu bölgede dini barışı sağlamak ve bazı insanların dini inançlarının hak edilmemiş ve aşă̆ılayıcı bir saldırıya konu olduğu duygusuna kapılmasını önlemek amacıyla hareket etmiştir. Söz konusu dönemde, yerel koşullar ışığında, böyle bir tedbire ihtiyaç olup olmadığı, ulusal otoritelerin uluslararası yargıçtan daha iyi değerlendirebileceği bir şeydir. Eldeki davanın bütün koşulları göz önüne alındı̆̆ında, AIHM, Avusturya otoritelerinin takdir payını aşmış olduğu kanaatine ulaşmamıştır. Dolayısıyla filme el konulması 10. maddenin bir ihlalini oluşturmamaktadır (Mocovei, 2005, s.72)."

Mahkeme, dini olarak kutsal kabul edilen değerler hususunda yasayla öngörülmüş olmak kaydıyla ulusal mahkemelerin kararlarına uymaktadır. Bu durumda bir dince kutsal kabul edilen değerlerin açı bir şekilde ihlalinin kanunla düzenlenmesi halinde ifade özgürlüğünün sınırları arasında yer aldığının genel kabul gördügünü söylemek mümkündür.

Diğer taraftan sadece "Hz. Muhammed'in tasvir edilmesi" bu meşru sınırlamalara dâhil midir? Nefret söylemi içermeyen veya kutsal kabul edilen değerleri rencide etmeyen karikatürler ifade özgürlüğünün koruması altında mıdır? Örneğin Charlie Hebdo'nun Hz. Muhammed'in yüzünü tasvir eden ve "Her şey affedildi" başlıklı kapağı ifade özgürlüğünün sınırlarını aşmakta mıdır? İslam dinine inanmayan, başka 
dine mensup ya da ateist kişiler, inanmadıkları bir dinin kurallarına uymak zorunda birakılmalı midır?

Karikatür yapısı itibariyle muhalif bir duruş sergilemektedir. Mizahın temel esaslarından biri de eleştiridir. Bununla birlikte, karikatürün eleştiremeyeceği iktidar yoktur (://www.umut.org.tr/Upload/Document/document_ca5f01b9796a40f782b43262be5fd0a9.pdf, Erişim Tarihi: 22.05.2016). Sahip olduğu güçle dini iktidarı da siyasi iktidar ve ekonomik iktidardan ayırmak karikatüristler için mümkün görünmemektedir. Bu noktada, karikatür aracılığıyla eleştirilenin din mi yoksa dinin iktidarlar tarafından kullanılması ve yanlış uygulamaları mı olduğu da göz önünde bulundurulmalıdir.

Türkiye' de Cumhuriyet Gazetesi, 15 Ocak 2015 tarihli sayısında 16 dilde yayımlanan Charlie Hebdo'nun 16 sayfalık özel sayısından 4 sayfayı, gazeteyle birlikte yayımladı. Halkın bir bölümünün tepkisini çeken bu durum karşısında Cumhuriyet gazetesinin Şişli'deki binasında güvenlik önlemleri alınmak zorunda kalındı.

Charlie Hepdo saldırısının Türkiye açısından önemli bir sonucu da saldırı sonrasında söz konusu karikatürleri sayfalarına taşıyan birçok gazeteden biri olan Cumhuriyet gazetesinin ve gazetenin iki yazarının durumudur. Nitekim Cumhuriyet Gazetesi yazarlarının mahkûmiyetiyle sonuçlanan Charlie Hepdo davasında Cumhurbaşkanı Recep Tayyip Erdoğan'ın çocukları Bilal ve Sümeyye Erdoğan ile Esra Albayrak ve eşi Berat Albayrak'ın da aralarında bulunduğu bin 280 müşteki yer almıştır.

\section{Sonuç}

İnsanların topluluk halinde yaşamaya başladı̆̆ı andan itibaren var olan mizah, toplumsal yaşamın gerek ve ihtiyaçlarına göre zaman içinde türlere ayrılmaktadır. Bu türler sabit kabul edilmez. Tarihsel süreç içinde gelişen ve değişen toplumsal yaşam biçimleri farklı mizah türlerini de beraberinde getirmektedir. Nitekim sözlü dönemde hiçbir etkinliğe sahip olmayan karikatürün bir mizah türü olarak basınla birlikte doğması da bu durumun bir ürünü olarak karşımıza çıkmaktadır. Karikatür; basının dördüncü güç olarak iktidarı denetleme, halkı aydınlatma ve muhalefet gibi 
görevlerini mizahın kökeninde yer alan eğlence ve hoşgörü kavramlarından aldığı destekle oldukça etkili ve sert bir dille gerçekleştirme hakkını kendinde görmüştür.

Bununla birlikte, karikatürü ve mizahı salt bir muhalefet aracı olarak görmek kanımızca eksik ve yanlış bir bakış açısı doğuracaktır. Nitekim karikatür de mizah da aynı zamanda sanatsal boyutuyla karşımıza çıkmakta ve özünde gülümsetme, güldürme hedefi taşımaktadır. Bir başka deyişle karikatür, kusurları abartıp büyüterek gülümsetmeyi hedefler. Eleştiri vasfını iktidarların ciddi yüzüne karşı çok da adil olmayan bir silahla- okuyucuyu gülümseterek- yerine getirir. Bu da ciddi bir hava taşıyan siyasete ve politikacılara yönelik en büyük tehdit olarak karşımıza çıkmaktadır.

Karikatürün günümüzdeki anlamıyla ortaya çıkması, basının günümüzdeki etkinliğini kazanması ile mümkün olmuştur. Bir başka deyişle mizah, kâğıda geçirilirken dönemin şartlarına, beklentilerine ve ihtiyaçlarına yönelik yeni bir araç edinmiştir.

Gerek Türkiye coğrafyasındaki tarihsel sürecine gerekse günümüzdeki karikatür savaşlarına ve karikatüristlere açlan davalara baktığımızda karikatürün salt bir sanat dalı, özel yeteneğe bağlı bir meslek değil; özgün bir ifade biçimi olduğu açıkça görülmektedir. Nitekim mizah, ülkemizde ifade özgürlügünün en etkin ve güçlü silahı olarak karşımıza çıkmaktadır. Öyle ki basın özgürlüğünün medya ve iktidar arasındaki ekonomik ilişkilere kurban verildiği ve medya kuruluşlarının oligopolleşerek hüküm sürdüğü günümüz şartlarında, görece küçük ölçekleri ve görece bağımsız karakterleriyle mizah dergileri, ifade özgürlüğü savaşına ve muhalefet hakkını kullanmaya devam etmektedirler. Değişen tek husus, muhalif gazetecilerin azaldığı bu dönemde karikatüristlerin daha fazla göz önünde olmasıdır.

Karikatür, kamunun desteğiyle kamusal bir görev ifa ettiği varsayılan gazeteciliğin mizahla birleştiği en keskin noktayı oluşturmaktadır. Bir başka deyişle, karikatür, mizahın sanat ve gazeteciliğin kesiştiği noktada yer almaktadır. Gazetecilerin elindeki masum görünüşlü bu silah, sadeliği ve kolay anlaşılır haliyle aynı zamanda en etkin olanıdır. Gazeteci, karikatürle mizahı kullanarak ispat yükümlülüğü taşımadan, geniş kitleleri kendi düşüncesinde ikna edebilir; bunun için ayrıntılı açıklamalara girmesi ya da düşüncelerini ispat etmesi gerekli değildir. Karikatür, zaten 
"abartı"dan oluşmaktadır ve doğruluk iddiası taşımaz. Bununla birlikte, ilk bakıştaki iddiasız görünümüne karşılık karikatür, tarih boyunca halk üzerindeki etkisinin farkında olan siyasi iktidarların korktukları ve engellemeye çalıştıkları bir araç olmuştur. Ülkemizde de mizah dergilerine ve karikatüristlere yönelik davalar sadece hakaret davalarından oluşmamakta; dini değerleri aşağılama, müstehcenlik ve 301. madde gibi TCK kapsamında suç olarak düzenlenen diğer unsurlar da mizah dergilerinin yasal yaptırımlar ya da tehdit ve baskıyla karşılaşmasına neden olabilmektedir.

Türkiye'de Cumhuriyetin ilanından sonra en keskin ve sistemli biçimde Markopaşa'yla başlayan ve Gırgır'la devam eden "karikatürün siyasi iktidara karşı savaşı"nın günümüzde muhalif duruşları ve haftalık tirajları göz önünde bulundurulduğunda, Uykusuz ve Leman dergileriyle devam ettiğini söylemek mümkündür.

Ülkemizde karikatür, doğuşundan itibaren güçlü ve etkili bir muhalefet aracı olmuş ve bu nitelikleri itibariyle iktidardaki güçler tarafından baskı altına alınmaya çalışılmıştır. Tarihsel sürece bakıldığında da özellikle toplumda ekonomik ve sosyal bir gerilemenin bozulmanın meydana geldiği durumlarda hem mizahın ve karikatürün hem de onlara uygulanan baskının arttığı görülmektedir.

Ülkemizde 2004 yılından itibaren gerek Basın Kanunu gerekse Türk Ceza Kanunu değişmiş; ifade özgürlüğü ile çelişen maddeler kaldırılarak "demokratikleşme" yoluna gidilmiştir. Ancak kanun maddeleri üzerinde gerçekleştirilen bu iyileştirmenin açılan davaların sayısında bir azalma meydana getirdiğini söylemek mümkün gözükmemektedir. Nitekim Leman ve Penguen dergilerine açlan davalar, Cumhuriyet gazetesinin iki yazarına Charlie Hepdo dergisinin karikatürlerine köşelerinde yer verilmesi nedeniyle ikişer yıl hapis cezasının verilmesi, karikatüristlerin neredeyse tamamının tazminat davalarına ilişkin çekinceleri nedeniyle otosansür uyguladıklarına ilişkin söylemleri ve buna rağmen muhalif çizgide yer alan neredeyse bütün karikatüristlerin açılmış davalarının olması bunun önemli bir göstergesidir. Bu noktada hakaret ve eleştiri arasındaki sınırın çizilmesinde basın özgürlüğü lehine bir duruş sergilenmesi zorunlu görünmektedir. Bununla birlikte karikatür eğitiminin yaygınlaştırılması ve karikatürün toplum tarafından benimsenmesi de iktidarları daha fazla hoşgörüye itecektir. 


\title{
EXTENDED ABSTRACT
}

\section{Caricature and The Freedom of Speech}

\author{
Zeynep Burcu Şahin \\ Istanbul Gelişim University
}

Caricature deals with the subjects it deals with in a short and concise way; it is a kind of cartoon pic-ture that usually exaggerates and sometimes distorts the truth to laugh, think and at the same time pinch. This innocent gun in the hands of journalists is the most effective at the same time as it is sim-plicity and easy to understand. The journalist can persuade large masses in their own minds before carrying out any proof of obligation using comic strips. It is not necessary to elaborate on this or to prove their opinions. Cartoons are already composed of "exaggeration" and do not bear the righteous-ness. for all that the caricature has become a means by which political powers who are aware of the influence over the people throughout history have been frightened and trying to prevent.

As a form of political satire, the caricature began to share the fate of the press in terms of restrictions and censorship long before it was included in legal texts as part of the press and freedom of the press. From this point of view, it is no coincidence that the caricature adopted and developed in England, which established a democratic regime relative to other European countries at the beginning of the 17th century, rather than the homeland of Italy. Caricature poses a threat to political and economic power, legal disputes arise between the ruling and cartoonists in this direction. At this point, it should not be forgotten that the cartoons are also subjected to the same rights, responsibilities and limitations as the freedom of the press, which is covered by press freedom.

The lawsuits against humor magazines and caricaturists in our country do not consist solely of insults humiliating religious values, obscenity and Other elements, such as Article 301, which are organized as criminal offenses under the Turkish Penal Code, may also cause humorous journals to face legal sanctions or threats and oppression. 
When we both look at the historical context of caricature in Turkey and the current caricature wars and the lawsuits, it is clearly seen that caricature is not only an a profession subject to a special ability, but an original form of expression. As a matter of fact, caricature appears to be the most effective and powerful weapon of freedom of expression in our country.

In today's conditions, where freedom of the press is sacrificed for the economic relations between media and power, and media prevail in oligopolization, with their relatively small scale and independent characters,caricature magazines, continue to use the right to freedom of expression and the right to opposition. The only thing that changes is that cartoonists are more concerned in this period when opposition journalists are declining.

How democracy is associated with personal rights and freedoms in a country is directly related to the balance of relations between society and political power, and to the historical, cultural, economic, religious and political infrastructure that constitute this balance. Similarly, the point of view of freedom of expression in the country in question will be determined by the elements mentioned above.

The situation in which the balance deteriorates against freedoms and social conscience brings with it a strong opposition. When we evaluate both the historical point of view and the agenda of the country in the past years, it is seen that there are periods in which the pressure element of the periods in which humor and caricature are most effective are increased.

Caricature in our country has been a powerful and effective tool of opposition since its birth and it has been tried to be put under pressure by the ruling forces. When we look at the historical process, it is seen that the humor and the caricature and the repression applied to them increase especially in cases where the economic and social decline in society has occurred.

In June 2014, Turkey, met with young people's unexpected response who succeeded in isolation from the apolitization process of the $80 \mathrm{~s}$ and a described as " 90 's genereation" with the first civil disobedience action in the history of the Republic. This incident, which is known as the Gezi Park protests, has brought with it an opposition that contains intense humor against the politics which is considered to be serious in our country. These shares, spreading to a relatively large number of people through 
social media, are meaningful in terms of demonstrating the power of an opposition that includes humor in our country.

Lawsuits against humor magazines and cartoonists in our country do not only consist of defamation cases; humiliation of religious values, obscenity and other elements regulated as criminal under the Turkish Penal Code (Article 301) may cause humor magazines to face legal sanctions or threats and pressure.

Although it encounters oppression and censorship every period and in some cases exceeds the limits of criticism, , cartoon, with all the power of humor and vitality continues to stand in Turkey. Humor magazines like Leman and Uykusuz, which are still in use today, are the most important indicators of this.

However, it is also seen that humor magazines are decreasing in number. Finally, in April 2017, Penguen magazine announced that they would put four more points and put an end to their lives.

In Turkey, both the Press Law and the Turkish Penal Code have changed since 2004; aiming democratization by removing the contradictions with freedom of expression. However, it is not possible to say that this improvement on the articles of law has caused a reduction in the number of cases filed.

In fact, the lawsuits against Leman and Penguen magazines, two writers of Cumhuriyet newspaper sentenced to two years of imprisonment because of the publication of the caricatures of Charlie Hepdo magazine, almost all of the caricaturists speech that refer that they applied self-censorship due to their reservations about compensation cases and however, almost all of the cartoonists in the opposition line had filed lawsuits are an important indicator of this.

At this point, it seems necessary to exhibit a stance in favor of press freedom in drawing the border between insult and criticism. In addition, the dissemination of caricature education and the adoption of the caricature by the society will lead to more tolerance. 


\section{Kaynakça / References}

Akad, M. (1976). Baskı gruplarının siyasi iktidarla ilişkileri. İstanbul: Fakülteler Matbaası.

Arık, B. (1998). 1980'den sonra yaşanan toplumsal değişim ve karikatürün değişen işlevi: Değişen toplum değişen karikatür. İstanbul: Türkiye Gazeteciler Cemiyeti Yayınları.

Arık, B. (2002). Apolitik mizah tartışmalarına tarihsel bir bakış. İstanbul Üniversitesi İletişim Fakültesi Dergisi, 17, 89-104.

Avcı, A. (2003). Toplumsal Eleştiri Söylemi Olarak Mizah ve Gülmece. Birikim Dergisi. 15.03.2018 tarihinde http://www.birikimdergisi.com/birikim-yazi/3891/toplumsal-elestiri-soylemi-olarakmizah-ve-gulmece\#.XBDKrXQzbIU adresinden erişilmiştir.

Balcıoğlu, S. (1987). Cumhuriyet dönemi türk karikatürü. Ankara: Türkiye İş Bankası Kültür Yayınları.

Çeviker, T. (1986). Gelişim sürecinde Türk karikatürü-I. İstanbul: Adam Yayınları.

Erçetin, G. (1999, 11 Şubat). Karikatürcü çizgiyle düşünür. Cumhuriyet. Koloğlu, O. (2005). Türkiye karikatür tarihi. İstanbul: Bileşim Yayınları.

Macovei, M. (2005). Avrupa insan hakları mahkemesi'nin 10 maddesi'nin uygulanmasına ilişkin kılavuz. İnsan Hakları El Kitapları No:2.

Morreal, J. (1997). Gülmeyi ciddiye almak. İstanbul: İris Yayıncılık.

Sanders, B. (2001). Kahkahanın zaferi. (Çev. K. Aysevener ve Ş. Soyer). İstanbul: Ayrintı.

Oskay, Ü. (2000). Tek kişilik haçlı seferleri. İstanbul: İnkılap Kitabevi.

Öngören, F. (1983). Cumhuriyet dönemi Türk mizahı ve hicvi. Ankara: Türkiye İş Bankası Kültür Yayınları.

Özocak, G. (2011). Türkiye'de siyasi iktidarın mizahla imtihanı: Ifade özgürlüğü ve karikatür. TBB Dergisi. http://tbbdergisi.barobirlik.org.tr/m2011-94-710 adresinden erişilmiştir. ss.259-294

Danimarkalı Bakandan Karikatür İtirafı!, 22.05.2017 tarihinde http://www.aktifhaber.com/danimarkali-bakandan-karikatur-itirafi-891776h.htm adresinden erişilmiştir.

Charlie Hebdo' dergisinde deprem. 20.05.2017 tarihinde http://www.netgazete.com/dunya/-charlie-hebdo-dergisindedeprem-701193 adresinden erişilmiştir. 
Blakemore C. ve Jennett. S. "Caricature." The Oxford Companion to the Body. 2001. Encyclopedia.com: 20.02.2016 tarihinde http://www.encyclopedia.com/doc/1O128-caricature.html adresinde erişilmiştir.

Erdoğan karikatürleri külliyatı'na yenileri eklendi. 11.05.2017 tarihinde http://www.diken.com.tr/dunyaca-unlu-karikaturistler-musakartla-dayanisma-icin-erdogana-karsi-birlesti/ adresinden erişilmiştir.

Fransiz basınınin en yaramazı: Charlie Hebdo. 20.05.2017 tarihinde http://tr.euronews.com/2012/09/21/fransiz-basininin-en-yaramazi-charlie-hebdo/ adresinden erişilmiştir.

Durutuna, G. (2012, 12 Temmuz). Harakiri'nin kapanması 'bayan yanı' gibi... 26.05.2016 tarihinde http://www.ntv.com.tr/arsiv/id/25365256/ adresinden erişilmiştir.

Karaman, N. (2015, 8 Nisan). Karan ve Çetinkaya'ya Charlie Hebdo davası. 30.05.2016 tarihinde http://www.sabah.com.tr/gundem/2015/04/08/karan-ve-cetinkayaya-charlie-hebdo-davasi adresinden erişilmiştir.

Penguen'in kapağına 7 bin TL ceza. 25.03.2017 tarihinde http://www.cumhuriyet.com.tr/haber/turkiye/235611/Penguen_in_kapagina_7_bin_TL_ceza.html adresinden erişilmiştir.

Penguen dergisi kapanma nedenini takipçileriyle paylaştı. 26.04.2017, 21.03.2018 tarihinde http://www.haberturk.com/kultur-sanat/haber/1474710-penguen-dergisi-kapanma-nedenini-takipcileriylepaylasti adresinden alındı.

Skandal Karikatür İçin 1 Yıl Hapis. 28.09.2011, 30.05.2017 tarihinde http://www.aktifhaber.com/skandal-karikatur-icin-1-yil-hapis498008h.htm adresinden erişilmiştir.

Şahin, Ü. Çizginin Gücü: Karikatür ve Sansür. 26.06.2017 tarihinde http://www.umut.org.tr/Upload/Document/document_ca5f01b9796a40f782b43262be5fd0a9.pdf adresinden erişilmiştir.

11.05.2017 tarihinde http://www0.sondakika.com/haber/haber-turkiyede-karikaturistlere-hapis-cezasi-7116710/ adresinden erişilmiştir.

02.03.2018 tarihinde http://bianet.org/bianet/bianet/105021-basbakanindava-actigi-leman-dergisine-kufur-ve-tehdit adresinden erişilmiştir. 
09.05.2017 tarihinde http://www.tdk.gov.tr/index.php?option=com_gts\&arama $=$ gts\&guid=TDK.GTS.5730897dcc16c0.-90659314 adresinden erişilmiştir.

11.05.2017 tarihinde http://www.gazetevatan.com/penguen-e-bir-davadaha-49852-gundem/ adresinden erişilmiştir.

11.05.2017 tarihinde http://www.diken.com.tr/musa-kart-gerceklericizdim-dedi-erdoganin-actigi-11-aralik-davasindan-beraat-etti/ adresinden erişilmiştir.

11.05.2017 tarihinde http://www.bianet.org/bianet/ifade-ozgurlugu/106803-reco-kenesi-nden-kurtulan-leman-ahlaksizlik-tan-mahkemelik adresinden erişilmiştir.

02.03.2018 tarihinde https://www.birgun.net/haber-detay/iktidar-mizahsevmez-64772.html adresinden erişilmiştir.

09.02.2017 tarihinde http://www.e-skop.com/skopbulten/\%E2\%80\%9Cutopya-acligi\%E2\%80\%9D-olarak-gezinin-mizahi/1719 adresinden erişilmiştir.

19.02.2017 tarihinde http://tr.wikipedia.org/wiki/Leman adresinden erişilmiştir.

02.03.2018 tarihinde http://www.akdagsaydut.com.tr/as_yazilar_orta.php?subaction=showfull\&id=1186940446\&archive $=\&$ start_from $=\& u$ cat $=10 \&$ adresinden erişilmiştir.

12.03.2017 tarihinde http://www.aboutfacesentertainment.com/pages/caricature-history.html adresinden erişilmiştir.

\section{Kaynakça Bilgisi / Citation Information}

Şahin, Z. B. (2019). Karikatür ve ifade özgürlügü̈. OPUS-Uluslararası Toplum Araştırmaları Dergisi , 10(17), 2208-2244. DOI: 10.26466/ opus.515034 